\title{
From Teaching to Thinking to Situating Practice
}

\author{
Narda Nelson
}

Narda Nelson is a pedagogist and researcher at University of Victoria Child Care Services and a member of the Common Worlds Research Collective and Early Childhood Pedagogies Collaboratory. Drawing on her master's in child and youth care and her background in gender studies, Narda takes an interdisciplinary approach to early childhood research and practice with a particular focus on reimagining ethical futures with plant, animal, and waste flow relations in early childhood. Email: nelsonn@uvic.ca

\author{
Book Review: From Teaching to Thinking: A Pedagogy for Reimagining Our Work \\ Ann Pelo \& Margie Carter \\ Lincoln, NE: Exchange Press, 2018402 pp. \\ ISBN: 978-0-942702-03-3
}

\begin{abstract}
From teaching to thinking. From instruction to inquiry. How do we support the development of an investigative attitude towards life? What does a culture of inquiry look like? How do we begin telling a new story that will transform how we think and work? (Pelo \& Carter, 2018, p. 52)
\end{abstract}

From Teaching to Thinking makes a thoughtful new contribution to the field of early childhood education (ECE). In it, Seattle-based teacher-educators, pedagogical consultants, and authors Ann Pelo and Margie Carter (2018) invoke 30 years of experience to weave stories from practice with questions aimed at unsettling the authority of assessment-driven approaches in the field of ECE. Central to their project is a call for educators and pedagogical leaders to cultivate a culture of inquiry with young children beyond prescriptive narratives promoted through standardized educational discourse. Pelo and Carter take an emergent, Reggio-inspired approach to reimagining the role of the educator, pedagogical facilitators, professional learning, planning, and other subjects in ECE. Their desire to think expansively in pedagogy and practice in early childhood is a welcome departure from the field's overwhelming impulse to reach toward theme-based learning and scripted curricular engagements. It will appeal to early childhood educators, administrators, pedagogical facilitators, and practitioners who are interested in challenging prescriptive approaches to curriculum and pedagogy through self-actualization and reflective practice while retaining a child-centered focus.

The book is comprehensive (402 pages long) and divided into 14 chapters. The authors strike a conversational tone throughout, using an active engagement structure wherein "Ann offers theory, story, and core concepts in her writing, and Margie offers a response that speaks to the ideas that especially stand out to her, and the questions for practice with which she wants us to engage" (p. 29). Grounded in the authors' shared commitment to cultivate an ethos of "justice and joy" while supporting educators to develop their full thinking-innovating potential, From Teaching to Thinking opens with existential questions we might do well to ask ourselves in these precarious times: "What kind of people do we want to be? What kind of world do we want to live in? ... What is the purpose of education, and how do we go about achieving it?" (p. 32). The first three chapters explore "The Heart of Education" (p. 32), "Creating a Culture of Inquiry" (p. 52), and "Rethinking Professional Learning" (p. 72), asking pedagogical leaders to reconsider their purpose through explorations of taken-for-granted terms and responsibilities in ECE, such as what it means to be reflective versus reactive in pedagogical practice. Pelo and Carter write:

The focus of the work of pedagogical leaders is to help educators become researchers who watch and listen to children with delight and curiosity, noticing the details of children's play and conversation in order to plan responsively.... Pedagogical leaders invite reflective, contextual thinking, and a willingness 
to linger in questions and not-knowing. Pedagogical leaders view teaching as experimentation. They encourage educators to seek out divergent points of view in order to increase complexity. Pedagogical leaders engage questions of ethics, emotion, and imagination as surely as they do matters of intellectual learning and skill development. (p. 60)

As the subtitle "A Pedagogy for Reimagining Our Work" suggests, the book provides a methodology for realizing the transformative practice Pelo and Carter espouse. This becomes more pronounced in the middle section of the book as they share "Principles for Reimagining Our Work" and "Thinking Lens," which are written through more of an instructional or "how-to" approach in the subsequent ten chapters. Developed in conjunction with their colleague Deb Curtis, the thinking lens is a tool applied through the book that Ann describes as "the thinking protocol" she has used in her teaching practice (p. 164). Stories from practice are presented throughout and the reader is asked to step back, think deeply, and apply the thinking lens to move forward. Their protocol includes the following guidance:

1) Know yourself. Open your heart to this moment.

2) Take the children's point of view.

3) Examine the environment.

4) Collaborate with others to expand perspectives.

5) Reflect and take action. (pp. 165-166)

One of the strongest applications of this protocol, for me, is in Chapter 12, where Pelo and Carter issue a challenge to reimagine pedagogical documentation as a vital and political part of practice:

Documentation is not reporting on what children know, or can do, or have learned; documentation is making visible how we educators think about a moment of a child's life that we've witnessed, and the insights and questions it holds for us. We do this in service of expanding our awareness and our capacity for responsiveness. (p. 261)

Pelo and Carter employ a sort of pragmatic idealism in promoting their "thinking lens" method by combining inspirational quotes from an array of childhood scholars (e.g., Peter Moss, Loris Malaguzzi), public figures (e.g., Zen master Thich Nhat Hanh), and feminist advocates and authors (e.g., bell hooks, Arundhati Roy), with stories from practice and how-to suggestions for creating protocols to support the process of significant change in pedagogy and practice. From Teaching to Thinking closes with a collection of testimonial "voices from the front lines" to reinforce their central point that reimagining pedagogy and practice in ECE is a transformative process worth pursuing.

From my perspective as an emerging Canadian pedagogist, the book's most valuable contribution is the politicized intentions it offers. Particularly salient is the authors' dedication:

We write this book for those who refuse to betray themselves or to betray children by adhering to marketplace outcomes and assessment-driven configurations of teaching and learning. We write this book for those who will not be complicit in the narrowing of education to the too-easy formula that says "quality" is achieved by lists of learning goals or by rating scales. We write this book for those who are ready to reimagine our work, and write a new and renewing story of early childhood education. (p. 29)

With these words in mind, the question, for me, becomes one of how this intention gets taken up-or not- 
within particular Canadian contexts. The authors' call for an expansive, visionary approach to early learning comes at an intensely paradoxical time within the field in Canada. On one hand, child care has been the focus of great attention over the past few years, thanks in part to the yet-to-be-realized Liberal federal government promise of delivering on a "fully inclusive" national childcare system (Cossette, 2017). At the same time, we see the Ontario Conservative government roll out deep cuts to education as they aspire toward more of a market-driven, service-based model of child care provision (Canadian Press, 2019), while in British Columbia, the minority NDP government has increased ECE funding and revised its Early Learning Framework (ELF) in what early childhood scholar Fikile Nxumalo (2018) describes as a hopeful step toward "radically re-imagining the kinds of curriculum and pedagogy that are needed for young children inheriting ecologically challenged lifeworlds" (para. 13). The Canadian educational landscape is complex and varied, requiring an added layer of self-reflection as to where and/ or how we position ourselves as pedagogical leaders and educators within specific community contexts before this book's potential can be realized. Indeed, what is the purpose of education? And, what is required to cultivate the conditions necessary for that purpose to flourish within a particular community of practice?

Because Pelo and Carter employ a generalized conceptualization of "humanity" throughout the text, engaging the book's ideas as Canadian educators and pedagogical leaders requires further effort to pay particular attention to the way we are situated within cultural, geographical, and historical contexts in order to avoid perpetuating the myth of an "anywhere childhood" in ECE. For example, in alignment with the Truth and Reconciliation Commission of Canada's (2015) calls to action, are we asking ourselves what our role has been within a colonial educational system and what is required of us to break with the habit of perpetuating erasures and ongoing violences that have been implicit in this and other Canadian systems before engaging with Pelo and Carter's self-reflective question of "who do we want to be?" From Teaching to Thinking's child-centered approach also raises questions for me in regard to how we might think expansively together to challenge instrumental and extractive modes of thinking in early childhood pedagogy and practice, for example, in the way landscapes, plants, and animals are often positioned as part of an enriching backdrop for childhood development in the field. Although addressing these questions would exceed the parameters of this review, I raise them here as part of a situated response to Pelo and Carter's invitation to think deeply with the book's provocative questions.

In conclusion, Pelo and Carter approach educators and pedagogical leaders with deep respect, seeing them as vital players in creating a transformative societal shift with children and families. Their call to reimagine roles and responsibilities in early childhood is a timely one and a positive jumping-off point for those of us in the Canadian early childhood field to reconsider our own role and responsibilities in co-creating transformative change within a rapidly changing landscape. 


\section{References}

Canadian Press. (2019, May 1). “Fees are going to go up": Ontario cancels \$50M child-care centres fund. Toronto Sun. Retrieved from https://torontosun.com/news/provincial/fees-are-going-to-go-up-ontario-cancels-50m-child-care-centres-fund

Cossette, M.A. (2017, June 12). Ottawa and provinces sign deal to create "fully inclusive" child-care system. CBC News. Retrieved from https://www.cbc.ca/news/politics/liberal-government-unveils-child-care-framework-1.4156348

Nxumalo, F. (2018, December 24). How climate change education is hurting the environment [editorial]. The Hill. Retrieved from https:// thehill.com/opinion/energy-environment/422720-how-climate-change-education-is-hurting-the-environment

Pelo, A., \& Carter, M. (2018). From teaching to thinking: A Pedagogy for Reimagining Our Work. Lincoln, NE: Exchange Press.

Truth and Reconciliation Commission of Canada. (2015). Truth and Reconciliation Commission of Canada: Calls to action. Retrieved from http://trc.ca/assets/pdf/Calls_to_Action_English2.pdf 